\title{
Negative Lymph Node
}

National Cancer Institute

\section{Source}

National Cancer Institute. Negative Lymph Node. NCI Thesaurus. Code C36174.

A clinical finding that a lymph node is free from cancer spread. 